\title{
AGATE AND AGATIZED-WOOD BEARING GRAVELS OF SOUTH-CENTRAL SASKATCHEWAN
}

\author{
by PAUL BROUGHTON*
}

Most gem and mineral collectors are familiar with collecting localitics in British Columbia, and indeed it is considered to be essentially the only focal point for western Canadian collecting. It is generally not well known, however, that the plains of southern Saskatchewan also have deposits of agate and agatized wood.

Southern Saskatchewan is characterized by a cover of Pleistocene till and gravel over Paleocene and upper Cretaceous sands, silts and clays, which are exposed in river valleys and badland areas. Where Ice Age deposits do not cap these bedrock sediments, an upper Tertiary gravel deposit frequently does. These Miocene and Oligocene age gravels are widely distributed over southcentral and southwestern Saskatchewan, often forming crests of hills and other higher elevation deposits. Such gravel deposits and gravel pits are ideal areas for prospecting for associated agates and agatized woods. During my several years of wandering the southern Saskatchewan countryside for notable agate accumulations, I have located what I consider to be amongst the best agate-bearing gravel deposits in this part of Prairie Canada.

It is the intention of this article to discuss recent finds of agate in the gravel pits around the town of Rockglen. I have located five good collecting areas in the Miocene-age Wood Mountain Formation, a sand and gravel accumulation associated with the southcentral portion of this province.

It is very difficult to give mileage directions from such and such a point to these deposits because of the confusing nature of the repetitious grid road system. Nevertheless, the locations are best described by the following legal section division designations to be used in conjunction with the available topographic maps of the area.

$\begin{array}{ccccccc}\text { Locality } & \text { LSD** } & \text { Section } & \text { Township } & \text { Range } & \text { Meridian } & \begin{array}{c}\text { Topographic } \\ \text { Map }\end{array} \\ & & & & & & \\ 1 & \text { NW } 6 & 32 & 2 & 30 & \text { W2 } & 72 \mathrm{H} / 4 \\ 2 & \text { NE 16 } & 23 & 1 & 2 & \text { W3 } & 72 \mathrm{G} / 1 \\ 3 & \text { SW } 8 & 12 & 1 & 1 & \text { W3 } & 72 \mathrm{G} / 1 \\ 4 & \text { NE } 7 & 7 & 1 & 30 & \text { W2 } & 72 \mathrm{H} / 4 \\ 5 & \text { NE } 9 & 33 & 1 & 29 & \text { W2 } & 72 \mathrm{H} / 4\end{array}$


the agate is simple dark brown to buff, translucent and weakly banded, and other specimens are reasonably fine quality carnelian. Once, during an afternoon of collecting I found four 1 - to 2 -inch diameter agates that were highly translucent, almost transparent, flawless and an even honey yellow color. They impress me as being able to cut into cabochons similar to fine amber. This particular variety of agate I personally prize, but that's but a matter of taste. Dull deep reddish brown jasper clasts are prolific throughout the gravel, but they hold little interest for me. The wood sections are well agatized and usually retain the distinct concentric ring structures. The woods tend to be dark gray to reddish brown, not very colourful but solid and well agatized. Sometimes a long section is uncovered, a foot or more in diameter. When sliced open it is a beautiful assortment of gray, white, buff brown, and deep red swirls, patches and streak patterns. I have also found a fossil primitive horse tooth at this locality.

Locality 3: This locality is reached by taking the grid road south from Rockglen for 10 miles, then 3 miles west and a half mile south. A farm house is situated opposite the gravel pit, at which permission must be asked

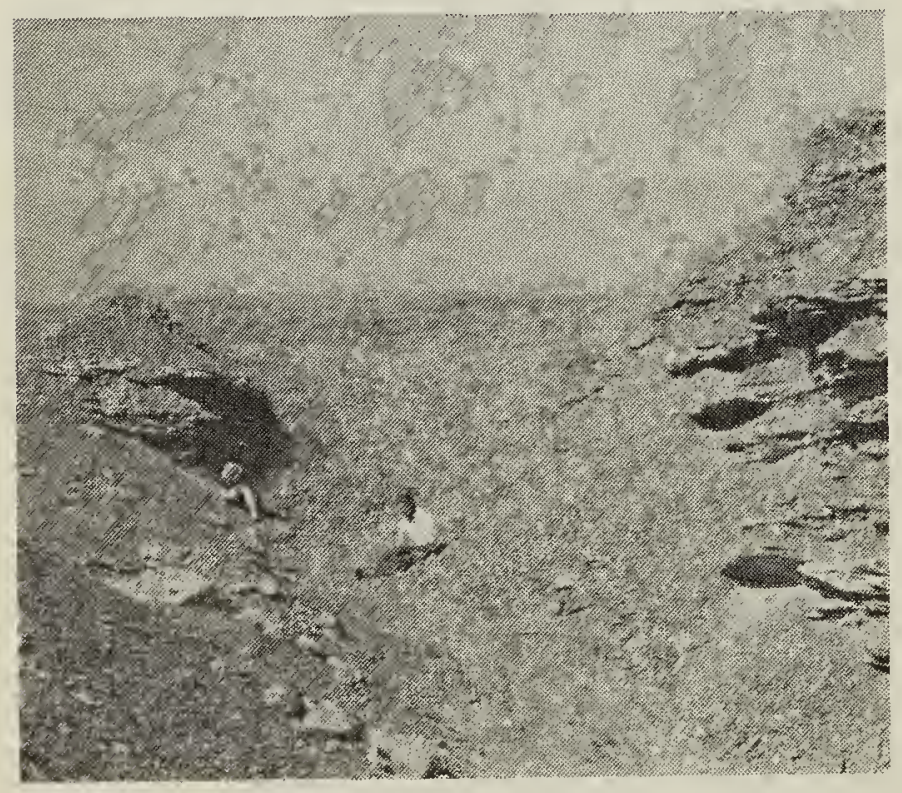

Searching for agates in a gravel pit of the Wood Mountain gravels. Paul Broughton to collect. There is a wide variety agates and woods similar to Locality but the overall size is smaller, usuall around an inch in diameter, or less fo the agates. The woods are wel agatized but relatively hard to find.

Locality 4: This gravel pit is reached b travelling 10 miles south fror Rockglen, 2 miles west, then a hal mile south to bring you against th base of a steep gravel hillside. Park the base and walk a quarter mile u the hillslope on the jeep trail to th gravel pit on the crest. The drive to th top is not recommended as there is $n$ place to turn around. The pit is smal and essentially but a scraping off of th hilltop. Nevertheless, there is plenty well agatized wood here, but relativel little agate.

Locality 5: This large gravel pit reached by taking the grid road sout from Rockglen for 6 miles, then miles east. The pit is visible from th road. I have not had very much succes at this locality, but friends report finr of petrified logs ten to a hundre pounds or more in weight. It is not to bad for agate of rather monotonou color, though, and should be in vestigated more thoroughly.

The above are the best agate colle ting localities that I know of in th part of southern Saskatchewan. prefer to hunt for agate and agatize wood in gravel pits, but fellow get seekers equally appreciate wandering across fields and hillsides hunting fo surface float. Many of my friends lik to walk the beaches of Fife Lake fo pieces of petrified wood exposed alon the shore. Many 40- or 50-pound ser tions have been recovered this wa: Fife Lake is 4 miles northeast Rockglen. I have never walked i shores because of recent high wate levels, but, someday I shall. The stor of that will be another day, anothe time. 